\title{
Patient Care in Chronic Diseases
}

\section{Lisa Shock*}

Duke University, USA

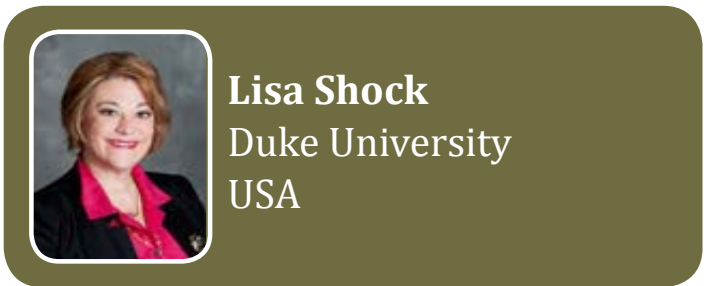

Journal of Patient care is an open access peer reviewed journal that publishes current development in the field of patient care. The Volume 2 , Issue 3 of the journal has published two research articles, three review articles and a mini review.

In the research article Ayman et al. analyzed the characteristics of patients with advanced hepato-cellular carcinoma (HCC) and determined their need for palliative care. Authors concluded that patients with HCC require early engagement ofspecialized palliative care program to address the disease symptoms. Authors concluded that the sole aim of the treatment should be improving the quality of patient's life [1]. Al-Agha et al. in their research article determined the association between anthropometric measurements and dietary intake (daily, weekly and rarely) in children aged 2-18 years. Authors found that different type of nutritional elements had different effects on children's growth [2]. Seeman discussed the effect of exercises on the antipsychotic side effects. Authors concluded that the bioavailability is the reasonfor the increase of side effects of antipsychotic drugs in intramuscular depot form [3].

In the review article Brown discussed the expanded role of community healthcare providers in offering health care and Turabian et al. discussed the teaching tools for training professionals working for the improvement of primary health care $[4,5]$. Yasser et al. discussed the outcomes of implementation of shared decision making in chronic inflammatory arthritis patients [6].

\section{References}

1. Ayman A, Azza AH, Yasser K, Kakil R, Jonas F, et al. (2016) The Role of Palliative Care in the Management of Patients with Advanced Hepatocellular Carcinoma: A Single Institution Experience. J Pat Care 2: 112

2. Al-Agha AE, Al-Baradi WR, Al-Rahmani DA, Simbawa BM (2016) Associations between Various Nutritional Elements and Weight, Height and BMI in Children and Adolescents. J Pat Care 2: 113.

3. Seeman MV (2016) Exercise and Antipsychotic Drugs. J Pat Care 2: 114.

4. Brown JL (2016) The Weak Link in Veterans' Medical Care: An Expanded Role for Community Healthcare Providers. J Pat Care 2: 115.

5. Turabian JL, Perez-Franco B (2016) Teaching Tools for the Mentor "Trainer" of Professionals Working in Primary Health Care Improving and Growing with Every Challenge. J Pat Care 2: 116

6. Yasser EM, Gaafary ME, Sayed S, Palmer D, Ahmed I (2016) Implementing Shared Decision Making In Clinical Practice: Outcomes of a New Shared Decision Making Aid for Chronic Inflammatory Arthritis Patients. J Pat Care 2 117.
*Corresponding author: Lisa Shock, Duke University, USA, Tel; 919-289-9126; E-mail: lisashock@gmail.com

Received December 20, 2016; Accepted December 21, 2016; Published December 27, 2016

Citation: Shock L (2016) Patient Care in Chronic Diseases. J Pat Care 2: e103. doi: $10.4172 / 2573-4598.1000 \mathrm{e} 103$

Copyright: (C) 2016 Shock L. This is an open-access article distributed under the terms of the Creative Commons Attribution License, which permits unrestricted use, distribution, and reproduction in any medium, provided the original author and source are credited. 